\title{
Die-cast Copper Motor Rotors: Die Materials and Process Considerations for Economical Copper Rotor Production
}

\author{
Dale T. Peters ${ }^{1}$, John G. Cowie ${ }^{2}$, Edwin F. Brush, Jr. ${ }^{3}$, and Stephen P. Midson ${ }^{4}$ \\ 1. Senior Advisor, Copper Development Association Inc., 27 Raintree Lane, \\ Hilton Head Island, SC 29926 USA \\ 2. Vice President, CDA Inc., 260 Madison Ave. New York, NY 10016 USA \\ 3. BBF Associates, 68 Gun Club Lane, Weston, MA 02193 USA \\ 4. Formcast Development, Inc., 100 S. Pecos St., Denver, CO 80223 USA
}

\section{Introduction}

For a high melting temperature metal such as copper $\left(\mathrm{T}_{\mathrm{m}}=1083{ }^{\circ} \mathrm{C}\right)$ to be economically pressure die cast, one or more suitable high temperature die materials must be identified and adapted to the process. This is a meaningful objective in terms of the rotor of the induction motor where aluminum has been the material of choice for the squirrel cage structure because this lower melting metal is readily die cast. A fabrication process other than pressure die casting is difficult to imagine. Because of copper's higher electrical conductivity, substitution of copper for the aluminum would increase the electrical energy efficiency of the induction motor and potentially provide benefits in manufacturing economics and weight savings, depending on design objective. Copper rotor casting experience and performance of motors equipped with copper rotors are detailed in another paper in this conference. At the 1999 EEMODS conference, a progress report on the die material investigation was presented [1]. This paper updates the results presented in 1999 and elaborates on the die failure mechanism and how die life can be substantially extended.

The principle failure mechanism in die casting dies is referred to as "heat checking" by die casters, but decarburization and softening of common die steels at the high surface temperature are also contributors [2]. Heat checking is a thermal fatigue phenomenon resulting from the rapid cyclic expansion of the die surface layer on contact with molten metal and the constraint of the surface by the much cooler inner portions of the die. In the cooling portion of each cycle, the outer layer falls to a temperature below that of the bulk of the die putting the surface under a large tensile stress that can exceed the yield point of the die material. This surface-to-interior differential expansion and contraction is greatly exacerbated in die casting high-melting metals such as pure copper. Consideration of the thermal fatigue failure mechanism suggests that the surface-to-interior $\Delta \mathrm{T}$ and 
resulting large strains can be minimized by raising the temperature of the bulk of the die insert. Herman et al [3] in 1975 and Doehler [4] in 1951 made this same suggestion. A practical system for heating and insulating the die inserts to maintain the high temperature critical to improving die life was developed and is described.. A thermal modeling exercise as part of this work allowed determination of the minimum temperature necessary to avoid stresses exceeding the material yield stress for various die materials.

\section{Experimental Method}

To avoid the expense and handling difficulties of using thousands of lamination stacks, a test die was devised for the die material tests. This test die consisting of six machined inserts shown in Fig. 1 allowed use of readily obtainable pieces of alloys and provided for evaluation of two or even three materials simultaneously. The gate area was designed to simulate a single gate of a multiple gate rotor die of a $15 \mathrm{Hp}$-motor to feed $0.9 \mathrm{~kg}$ of copper to the flat semi-circle at the top of the casting. A dry powdered release agent was applied immediately before each shot. The test die design is believed to be an aggressive test of die materials exceeding conditions the rotor die set experiences.

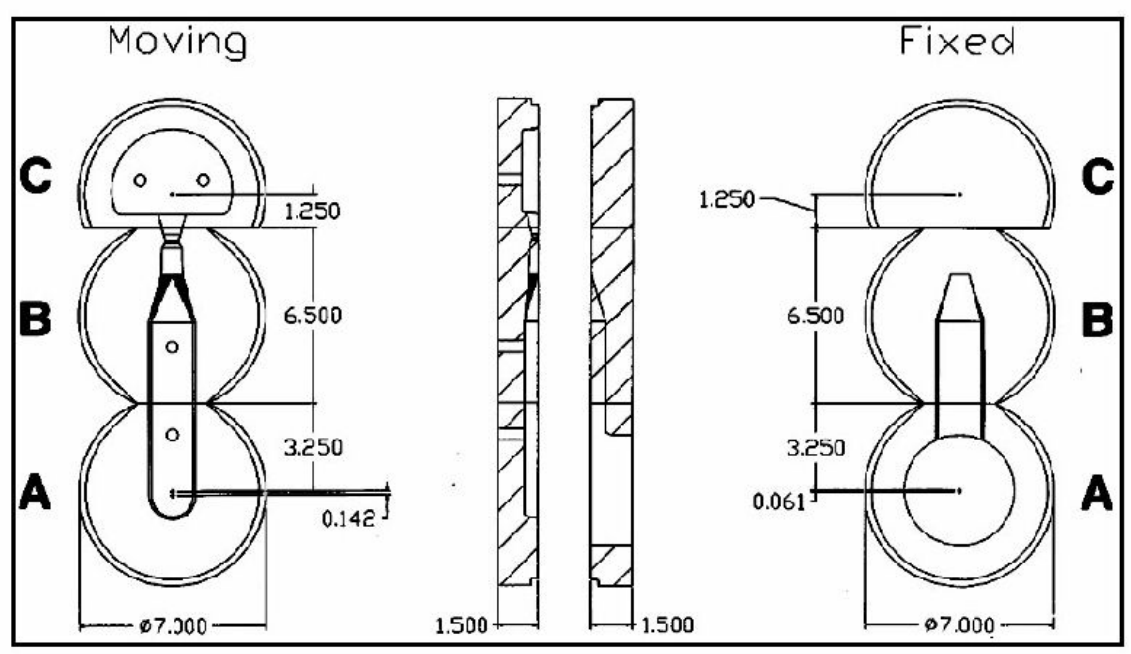

Fig. 1. Die material test die made up of six machined inserts.

Ladling molten copper from a holding furnace would make control of oxygen and hydrogen problematic. For this work, 3.6-kg charges of chopped wire rod (C11000 copper) was induction melted one shot at a time on a two minute cycle. This re- 
Die-cast Copper Motor Rotors: Die Materials and Process Considerations for Economical Copper Rotor Production 3Die-cast Copper Motor Rotors: Die Materials and Process Considerations for Economical Copper Rotor Production 3

quired a $60 \mathrm{~kW}$ power supply. Maximum utilization of the power supply was achieved by using two push-up furnaces alternatively switched to the supply.

660 metric ton real-time shot controlled Buhler machine at Formcast Development, Inc. was used for this study. For the die material trials, the ram speed during die fill was $1 \mathrm{~m} / \mathrm{s}$ and the final pressure was $49 \mathrm{MPa}$.

\section{3-D Computer Analysis of Die Thermal Profiles}

A 3-D computer analysis of heat transfer in the die material test inserts vividly showed the thermal gradients generated when the die is brought into contact with molten copper (K.D.Williams, Flow Simulation Services, Albuquerque, NM). This analysis was valuable in understanding the thermal fatigue failure mechanism and how to minimize or largely avoid it. The time to gate freezing and the number of shots to reach the equilibrium temperature profile were also obtained.

Temperature profiles in $\mathrm{H}-13$ die inserts were generated for this material in the test die geometry of Fig. 1. Die surface temperature distributions at the instant of filling with $1200^{\circ} \mathrm{C}$ molten copper and at points in time immediately thereafter were calculated. Since the die surfaces are generally coated with a mold release compound, a value for the heat resistance, $\mathrm{R}$, of this coating had to be selected. This was taken as $1^{\circ} \mathrm{Ccm}^{2} /$ watt, a value in the middle of the range found in the die casting literature. To avoid representational problems, the surface die surface temperatures calculated from the model have been shown as though they were "painted" onto the surface of the test casting. An example for the case of the instant of die cavity fill with $1200^{\circ} \mathrm{C}$ copper is shown in Fig. 2. Representations of this type for numerous scenarios are presented elsewhere [5]. In this case the casting surface will actually be hotter than the die surface because of the surface heat conducting resistance. In fact, in this example, the investigators assumed that coating the narrow gate region would be difficult and assigned a very low heat flow resistance to this region. Thus the die surface temperature in the gate region was essentially at the melting point of copper. This means that the surface of the gate region of the die insert had risen from the initial temperature of $200^{\circ} \mathrm{C}$ by $880^{\circ} \mathrm{C}$. Because of the low thermal conductivity of $\mathrm{H}-13$ tool steel, the body of the mold was still at $200^{\circ} \mathrm{C}$. This implies that the surface had a temperatureinduced strain of a least $1.19 \%$, an enormous strain to sustain on a cyclic basis.

Immediately after filling, the coated areas of the die surface were only in the range of $550-600^{\circ} \mathrm{C}$, or $350^{\circ} \mathrm{C}$ above the initial temperature and the bulk of the insert. The surface at the biscuit area at the end of the ram in the shot sleeve was at about $800-850^{\circ} \mathrm{C}$. 
4 Dale T. Peters1, John G. Cowie2, Edwin F. Brush, Jr.3, and Stephen P. Midson44 Dale T. Peters1, John G. Cowie2, Edwin F. Brush, Jr.3, and Stephen P. Midson4

At 0.5 seconds after casting, results showed that the temperature in the uncoated gate area had started to drop, but the rest of the die surface was getting hotter. The metal volume in the gate is small and with $\mathrm{R}$ taken as a very small value in this region, heat diffusion to the die steel is rapid. The longer coated surface areas had risen to the 700 to $800^{\circ} \mathrm{C}$ range. After 6.5 seconds, it was found that the gate area was relatively cold but coated areas of the larger volume sections of the casting had risen to 750 to $900^{\circ} \mathrm{C}$.

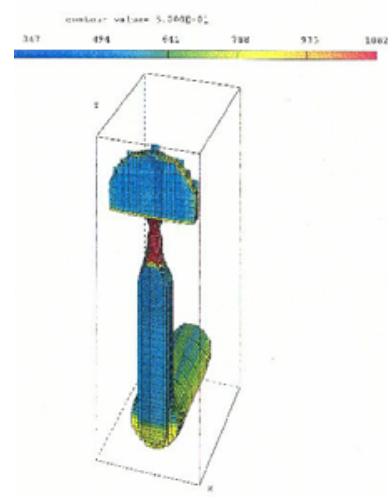

Fig. 2. Output of thermal modeling showing H-13 die surface "painted" onto the test casting at instant of fill with $1200^{\circ} \mathrm{C}$ copper.

Thus in the H-13 tool steel, we expect from these calculations that the die surface temperature will rise to values ranging from $825^{\circ} \mathrm{C}$ to over $1000^{\circ} \mathrm{C}$ everywhere outside the gate region (assumed to be uncoated in this example). These high temperatures occur even with a surface coating with a resistance of $1^{\circ} \mathrm{Ccm}^{2} /$ watt over these surfaces. These high surface temperatures imply that substantial surface strain occurs everywhere in the $\mathrm{H}-13$ dies.

It was clear that to achieve the higher average mold temperatures required to minimize the $\Delta \mathrm{T}$ between the die surface and interior associated with each cycle, and the resulting cyclic strain, it would be necessary to both insulate the die inserts from the backing steel and provide a source of heat directly to the inserts. Temperature distribution data of the type shown in Fig. 2 was obtained for a tungsten die set with an initial wall temperature taken as $650^{\circ} \mathrm{C}$ (assuming direct die insert heating and insulation). Although the gate area surface temperature was seen to be near the melting point of copper because of the low surface resistance assumed for this region, the remaining surface temperature was found to be only in the range of 750 to $800^{\circ} \mathrm{C}$, only a 100 to $150^{\circ} \mathrm{C}$ increase. The smaller increase compared to the H-13 example is in part due to the higher thermal conductivity of tungsten. 
Die-cast Copper Motor Rotors: Die Materials and Process Considerations for Economical Copper Rotor Production 5Die-cast Copper Motor Rotors: Die Materials and Process Considerations for Economical Copper Rotor Production 5

A model prediction of temperature-time profiles in a tungsten insert preheated to $380^{\circ} \mathrm{C}$ was generated using a die/copper contact resistance of $0.3^{\circ} \mathrm{Ccm}^{2} /$ watt. This prediction was compared to the measured temperatures during the shot with thermocouples located near the front, center and rear of the insert [5]. The agreement was excellent. A $\Delta \mathrm{T}$ of about $400^{\circ} \mathrm{C}$ between the front and rear of the insert was generated immediately after filling the die cavity. Calculations showed that this would lead to a plastic strain on each cycle. For tungsten, the minimum die temperature to assure strain and resulting stress below the yield point is $550^{\circ} \mathrm{C}$. It is important to note that with the ductile/brittle transition temperature being about $200^{\circ} \mathrm{C}$ for tungsten, the machine operator cannot use the first few shots to achieve the operating temperature without cracking the die.

In nickel-base alloy molds, the temperature gradient and resulting surface stress will be higher due to the lower thermal conductivity of these alloys. The minimum die temperature to assure that cyclic surface stresses remain below the yield point was estimated to be about $625^{\circ} \mathrm{C}$.

\section{Die Material Evaluation Tests}

\section{H-13 Die Steel}

An $\mathrm{H}-13$ die set was run to failure to establish a base line and to gain experience in die casting copper. To minimize thermal shock with the first few shots of molten copper, the dies and shot sleeve were preheated to about $350^{\circ} \mathrm{C}$ with an oxyacetylene torch. As expected, substantial physical damage was quickly evident after only about 20 shots. The run was continued for a total of 750 shots during which steady deterioration by heat checking, cracking and erosion at insert joints and ejector holes was taking place. The run was discontinued when ejection of the casting became difficult as copper solidified in the deep fissures. Electrical conductivity of the die-cast copper averaged $98 \%$ IACS.

\section{TZM and Anviloy}

TZM is a molybdenum-base alloy containing nominally $0.5 \% \mathrm{Ti}, 0.09 \% \mathrm{Zr}$ and $0.025 \%$ C. Anviloy 1200 is tungsten-base containing $4 \% \mathrm{Ni}, 2 \% \mathrm{Fe}$ and $4 \% \mathrm{Mo}$. The alloys were tested simultaneously in the test die configuration of Fig. 1. At this point in the die material investigation, the first heated die configuration had been designed and installed on the machine. This allowed preheating and maintaining the dies at $450^{\circ} \mathrm{C}$. This was the maximum temperature attainable with this initial heater array design and was about $100^{\circ} \mathrm{C}$ below the minimum required to avoid exceeding the yield strength at the surface suggested by the thermal modeling. Failure of one or more heaters during the first run of 500 shots resulted in operation at an even lower temperature for a portion of the run. Despite these prob- 
6 Dale T. Peters1, John G. Cowie2, Edwin F. Brush, Jr.3, and Stephen P. Midson46 Dale T. Peters1, John G. Cowie2, Edwin F. Brush, Jr.3, and Stephen P. Midson4

lems, no heat checking of either alloy was evident but minor cracking of the Anviloy inserts at sharp radii was noted.

A second run was carried out some weeks later with all heaters operating extending the total number of shots to 940. At this point, both the TZM and Anviloy inserts showed additional minor cracking at the ejector pin holes due to inadequate allowance for the higher thermal expansion of the steel ejector pins. Otherwise these die sets appeared to be capable of extended runs in this severe copper die casting exercise with no heat checking in the gate areas, contours, and flat surfaces. The TZM inserts did suffer serious surface degradation by oxidation because the surface reached temperatures above $700^{\circ} \mathrm{C}$ where the oxide melts and volatilizes. This problem makes uncoated TZM a poor choice for die casting pure copper.

This work indicates that with sufficient preheat and maintenance of the operating temperature at $550^{\circ} \mathrm{C}$, Anviloy is a suitable die material for die casting of pure copper. High base material and machining costs are deterrents to its use, but Anviloy may offer a viable alternative in a part or parts of the die, such as the runner or gate, where the incoming metal temperature or flow rate are extreme.

\section{Nickel-base Alloys}

Three very different types of nickel-base alloys were evaluated with two inserts of each alloy in the test die. INCONEL alloy 617 is a $22 \% \mathrm{Cr}, 12.5 \%$ Co alloy solid solution strengthened with 9\% Mo. INCONEL alloy 718 is a gamma prime strengthened alloy containing $15.5 \% \mathrm{Cr} 0.7 \% \mathrm{Al}, 2.5 \% \mathrm{Ti}$ and $0.95 \% \mathrm{Nb}$. INCONEL alloy 754 is a mechanically alloyed $20 \% \mathrm{Cr}$ alloy with small additions of $\mathrm{Al}$ and Ti. A dispersion of $\mathrm{Y}_{2} \mathrm{O}_{3}$ is the principle strengthener giving resistance to recrystallization and excellent retention of high temperature strength. In a run of 250 shots, the inserts were preheated to $350^{\circ} \mathrm{C}$ using the electrical resistance heaters and not permitted to fall below this temperature in the cooling portion of the cycle. Even though the 754 alloy has the highest strength at the copper melting temperature, these inserts began to show cracking in less that 50 shots. INCONEL alloy 718 began cracking in about 100 shots. Being a precipitationhardening alloy, alloy 718 would be expected to have very low strength near the surface which would reach the melting point of copper on each cycle but maintain its high tensile and yield values in the interior and back of the insert where ductility (17-19\%) is only fair. INCONEL alloy 617 showed only minor craze cracking after 250 shots at this low operating temperature $\left(275^{\circ} \mathrm{C}\right.$ below the minimum required). This test served to reveal alloy 617 as having the best combination of strength and ductility over the range of temperatures experienced by the insert.

A second extended run was done to evaluate the solid solution nickel-base alloys, INCONEL alloys 601, 617, and 625. Alloy 601 is a lower strength Ni-23\% Cr alloy with $1.35 \% \mathrm{Al}$. It has only $14 \%$ elongation at $1177^{\circ} \mathrm{C}$ and yield strength of only $15 \mathrm{MPa}$. Alloy 625 has $21.5 \% \mathrm{Cr}, 9 \% \mathrm{Mo}$ and 3.65\% $\mathrm{Nb}$ and has somewhat 
Die-cast Copper Motor Rotors: Die Materials and Process Considerations for Economical Copper Rotor Production 7Die-cast Copper Motor Rotors: Die Materials and Process Considerations for Economical Copper Rotor Production

higher tensile and yield strengths at room and intermediate temperatures, but is not quite as strong at $1100^{\circ} \mathrm{C}$ as alloy 617 . Ductilities of both alloys 617 and 625 are quite high ( $45 \%$ minimum over the range of temperature) but slightly higher in alloy 617. At the point in time of these runs, the array of heaters and insert insulation shown in Fig. 3 had been developed to the point that the preheat and operating temperatures could be maintained at $540^{\circ} \mathrm{C}$ and with further tweaking for the next run, to the $625-640^{\circ} \mathrm{C}$ range.

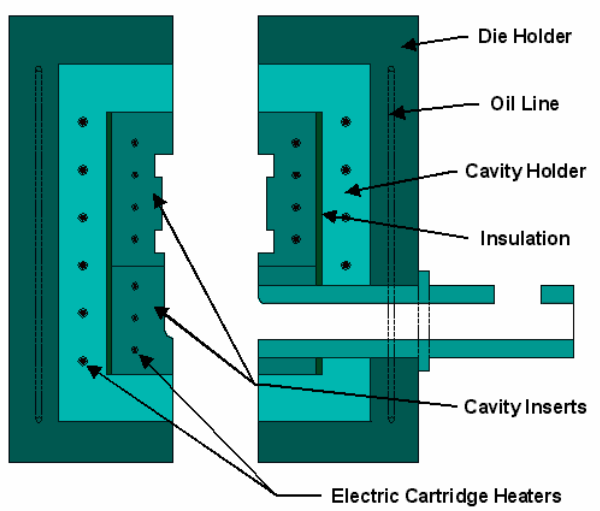

Fig. 3. Schematic illustration of placement of electric resistance and insulation in the die material test set-up developed in the course of this study.

In the course of an extended run with this die heating equipment, it became apparent that the amount of heat checking was markedly reduced as the operating temperature was increased. Finally in the last 330 shots at the highest operating temperature, there appeared to be no further deterioration of the die set. A total of 950 shots at the several progressively increasing operating temperatures had been made in this rather severe test. Clear distinctions between the three INCONEL alloys were difficult to discern. Alloy 601 may have somewhat inadequate tensile and rupture strengths for very long campaigns at or near $650^{\circ} \mathrm{C}$.

Chemical analysis of several copper test castings showed average iron pick-up of $65 \mathrm{ppm}, 5 \mathrm{ppm} \mathrm{Ni}$ and $0.074 \mathrm{wt} \%$ oxygen. The microstructures were quite sound. The electrical conductivity was higher than that of the castings from the $\mathrm{H}-13$ dies averaging $99.9 \%$ IACS. Elimination of the steel shot sleeve in favor of a nickelbase alloy sleeve would presumably further reduce the iron and increase conductivity slightly. 
8 Dale T. Peters1, John G. Cowie2, Edwin F. Brush, Jr.3, and Stephen P. Mid-

son48 Dale T. Peters1, John G. Cowie2, Edwin F. Brush, Jr.3, and Stephen P. Midson4

\section{Conclusions from Die Material Tests}

Extended production runs will be required to prove the point, but these tests show promise that the INCONEL alloys 617 and 625 operated in the $600-650^{\circ} \mathrm{C}$ temperature range are very promising die materials for long die life in large volume production of die-cast copper motor rotors. Although not tested in this study, Haynes alloy 230 is also a strong candidate die material. This alloy has slightly higher yield strength and ductility than alloy 617 and is weld repairable. Alloy 230 will be used in the first copper rotor production die set being built at this writing. An important conclusion from this work is that it is absolutely essential to operate at elevated temperature to extend die life. The higher die temperature reduces the surface-to-interior $\Delta \mathrm{T}$ on each shot which in turn greatly minimizes the cyclic expansion and contraction and thus the thermal fatigue mechanism causing heat checking and more severe cracking. Temperatures above $650^{\circ} \mathrm{C}$ are not required and in fact would reduce productivity by increasing cooling time. A practical die heating and insulation design has been developed.

\section{Acknowledgements}

This project was sponsored by the world copper industry through the International Copper Association, Ltd. and managed by the Copper Development Association Inc. Additional funding was provided by the U. S. Department of Energy Office of Industrial Technologies and the Air Conditioning and Refrigeration Technical Institute. Formcast Development, Inc., Denver, Colorado, provided the die casting equipment and expertise. Mr. Ruedi Beck of DieTec, GmbH, Gossau, Switzerland, designed the innovative approaches to heating die inserts.

\section{References}

1. D. T. Peters, J. G. Cowie, and E. F. Brush, Jr., "Die Casting Copper Motor Rotors: Mold Materials and Processing for Cost Effective Manufacturing" Proceedings of EEMODS Second International Conference, London, (1999).

2. J. C. Benedyk, D. J. Moracz, and J. F. Wallace, "Thermal Fatigue Behavior of Die Materials for Aluminum Die Castings." Trans. of SDCE, Paper No. 111 (1970).

3. E. A. Herman, J. F. Wallace, and A. A. Machonis, Copper Alloy Pressure Die Casting, p. 52, International Copper Research Association, New York, NY (1975).

4. H. H. Doehler, Die Casting, pp. 163-165, McGraw-Hill Book Co., Inc., New York, NY (1951).

5. D. T. Peters, J. G. Cowie, E. F. Brush, Jr. and S. P. Midson, "Use of High Temperature Die Materials and Hot Dies for High Pressure Die Casting Pure Copper and Copper Alloys", North American Die Casting Association Die Casting Congress, Rosemont, IL (2002). 